\title{
Elevated Aspergillus-specific antibody levels among HIV infected Ugandans with pulmonary tuberculosis
}

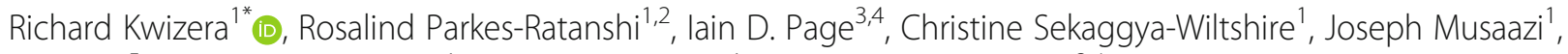
Jan Fehr ${ }^{5}$, Barbara Castelnuovo ${ }^{1}$, Andrew Kambugu ${ }^{1}$ and David W. Denning ${ }^{3,4}$

\begin{abstract}
Background: The incidence of tuberculosis (TB) is high among human immunodeficiency virus (HIV) infected Ugandans. Recent evidence suggests that Chronic Pulmonary Aspergillosis and Aspergillus sensitisation might be responsible for significant mortality in patients treated for tuberculosis in Uganda.

Methods: We retrieved and tested paired serum aliquots for $101 \mathrm{HIV}$-TB co-infected patients at the beginning and week 24 of TB treatment. We tested samples for Aspergillus-specific immunoglobulin $\mathrm{G}$ (lgG) and immunoglobulin $\mathrm{E}$ (lgE) using ImmunoCAPं; and Aspergillus-specific lgG and total serum IgE using Immulite ${ }^{\circledast}$ immunoassays. We compared antibody levels between baseline and week 24, relating them to selected baseline characteristics.

Results: $10 \%$ of the patients had elevated Aspergillus-specific lgE (Aspergillus sensitization) and Aspergillus-specific lgG antibodies were elevated in 9\% of the patients at the end of TB treatment. There was a significant fall in the Aspergillusspecific lgG antibody levels between baseline and week $24(P=0.02)$. Patients with cluster of differentiation $4(C D 4) T$-cell count $<100 \mathrm{cell} / \mathrm{s} / \mathrm{\mu l}$ and those who were not on anti-retroviral therapy at baseline had more elevated Aspergillus-specific $\lg$ antibodies ( $P=0.01, P=0.03$ ). The ImmunoCAP® Aspergillus-specific Ig $\lg$ antibody titres were higher at week 24 than baseline with more positives at week 24; even though the difference in means was small. However, this difference was statistically significant $(P=0.02)$. Pulmonary infiltrates were the commonest $x$-ray abnormality and only $5 \%$ of the patients had pulmonary cavities on chest $x$-ray at week 24.

Conclusion: These results suggest that Aspergillus infection may complicate active pulmonary TB and further studies including fungal culture and thoracic imaging may now be indicated to measure the prevalence of pulmonary aspergillosis complicating tuberculosis.
\end{abstract}

Trial registration: The SOUTH trial was registered prospectively. ClinicalTrials.gov Identifier: NCT01782950; Registration date: 4th February 2013; Last verified: 13th April 2015.

Keywords: Aspergillosis, HIV, Tuberculosis, Fungal diagnostics; serology

\section{Background}

Tuberculosis (TB) remains one of the major causes of morbidity and mortality worldwide with the highest burden found in Africa and Asia, mainly linked to the human immunodeficiency virus (HIV) epidemic [1]. The 2016 World Health Organization (WHO) report on TB revealed that there were an estimated 10 million new cases of TB in the

\footnotetext{
* Correspondence: kwizerarichard@ymail.com

'Infectious Diseases Institute, College of Health Sciences, Makerere University, P.O.BOX 22418 Kampala, Uganda

Full list of author information is available at the end of the article
}

year 2015 worldwide, with $11 \%$ having HIV. An estimated 1.8 million people died due to TB in 2015, including 0.4 million deaths due to HIV/TB co-infection. The incidence of TB among HIV patients in Uganda was estimated at 202 new cases per 100,000 population [2].

Due to the limited published data on fungal disease epidemiology in sub-Saharan Africa, a recent review attempted to estimate the burden of fungal infections in Uganda using specific populations [3]. In this review, chronic pulmonary aspergillosis (CPA) was estimated at $12-22 \%$ in TB patients with cavities and $1-4 \%$ in those 
without cavities. Considering post-TB data in Uganda, asymptomatic CPA was estimated at $7 \%$ with an additional 1.7\% having detectable Aspergillus-specific immunoglobulin G (IgG) antibodies with cavitation.

Recent work done in Northern Uganda has validated some of these estimates, with a CPA prevalence of $8.2 \%$, and $6.7 \%$ having cavities among patients who had been successfully treated for pulmonary TB within the last 7 years $[4,5]$. More results from this work showed Aspergillus-specific IgG antibody levels were raised in $26 \%$ of patients with "smear negative TB" and suggested that previously unrecognized CPA might be responsible for significant mortality in patients treated for $\mathrm{TB}$ in Uganda [6-8]. Beyond this limited data, little is known about the epidemiology of fungal colonisation and sensitisation, and their contribution to TB disease progress and treatment outcomes in Uganda where pulmonary TB is very common, in part driven by the high prevalence of HIV [9].

We hypothesized that patients with pulmonary TB may get colonized with Aspergillus during and in the post treatment period leading to a chronic lung infection and/or allergic fungal disease if the patient was presensitized to Aspergillus antigens. Pulmonary cavitation is a pre-disposing factor for CPA [10] and may or may not present together with Aspergillus sensitization. We therefore aimed to establish and compare Aspergillusspecific antibody levels among HIV-infected Ugandans with $\mathrm{TB}$, at the beginning and end of $\mathrm{TB}$ treatment;

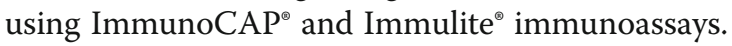

\section{Methods}

\section{Study design and population}

This was a nested cohort study under the "Study on Outcomes related to Tuberculosis and HIV drug concentrations in Uganda" (SOUTH) (ClinicalTrials.gov: NCT01782950). SOUTH was a prospective study investigating the correlation of anti-tuberculosis drug concentrations and TB treatment outcomes in HIVinfected individuals with pulmonary $\mathrm{TB}$ at the Infectious Diseases Institute, Kampala, Uganda [11]. All participants were HIV-TB co-infected patients above 18 years with a diagnosis of their first episode of pulmonary TB i.e. proven or highly suspected TB considered for TB treatment qualifying for 6 months (24 weeks) anti-TB drugs regimen (2 months HRZE [isoniazid $(\mathrm{H})$, rifampicin $(\mathrm{R})$, pyrazinamide $(\mathrm{Z})$ and ethambutol $(\mathrm{E})$ ] and 4 months $\mathrm{HR}$ [isoniazid $(\mathrm{H})$ and rifampicin (R)]). Patients with multi-drug resistant TB were excluded. Only $32 \%$ of the participants already had an HIV diagnosis with an average time since diagnosis of 53 days. The rest of the participants were diagnosed at TB screening. Each participant was followed up for 24 weeks.

\section{Study samples}

Samples used for this study were stored serum samples from the SOUTH study population (stored at $-80^{\circ} \mathrm{C}$ ). We cross checked the sample storage inventories to look out for participants that had a sample stored at beginning (baseline) and end of TB treatment (week 24). We included all patients with two aliquots i.e. one at baseline and one at week 24. Samples were then shipped and tested at the Mycology Reference Centre Manchester and Christie Hospital, Manchester, United Kingdom (UK).

\section{Study assays}

Testing was initially done using the ImmunoCAP ${ }^{\bullet}$ machine (ThermoFisher ${ }^{\oplus}$, previously Phadia) to check for levels of Aspergillus-specific IgG (Asp IgG) at baseline and week 24. Also, using ImmunoCAP Aspergillus-specific IgE (Asp IgE) antibody levels were checked at week 24 only. Further testing for total serum IgE (TIgE) levels at both baseline and week 24 was undertaken on the Immulite $2000^{\circ}$ machine (Siemens). Remaining serum was re-tested for Aspergillus-specific IgG levels using the Immulite machine (Additional file 1).

\section{Assay cut-offs}

We used a cut-off of $40 \mathrm{mg} / \mathrm{l}$ for the ImmunoCAP Aspergillus-specific IgG levels as recommended by manufacturer, and a cut-off of $20 \mathrm{mg} / \mathrm{l}$ for the Immulite Aspergillus-specific IgG levels based on preliminary results of a cross-sectional survey in Uganda [4]. Variations in the cut-off for total serum IgE have been reported ranging from 150 to $1000 \mathrm{UI} / \mathrm{ml}$ [12]. However, a cut-off of $1000 \mathrm{UI} / \mathrm{ml}$ is recommended for diagnosis of allergic bronchopulmonary aspergillosis (ABPA) [13]. Therefore, for our study, we used a cut-off of $170 \mathrm{UI} / \mathrm{ml}$ to check for general allergy and a cut-off of $1000 \mathrm{UI} / \mathrm{ml}$ as a screen for evidence of ABPA. A cut-off of $0.35 \mathrm{kU} / \mathrm{l}$ was used for Aspergillus-specific IgE levels as recommended by the manufacturer.

\section{Data analysis}

Data were analyzed using STATA ${ }^{\bullet}$ version 13 (STATA, College Station, Texas). Our primary data analysis aimed at comparing the Aspergillus-specific IgG antibody levels at baseline compared with week 24, and relating them to baseline demographics and clinical parameters (Additional file 1) at a 95\% confidence interval.

\section{Results}

\section{Study population characteristics}

Of 268 patients in the SOUTH study, we selected all participants $(n=101)$ with a pre and post treatment serum sample; that were enrolled into the SOUTH study between March 2013 and July 2014. Of participants, 56\% 
(56/101) were men and the median age of all participants at $\mathrm{TB}$ diagnosis was 33 years (interquartile range (IQR), 27-38). All participants were HIV-infected adults with a median baseline CD4 T cell count of 155 cells/ $\mu$ l (IQR, $31-269, n=98)$. Only 31\% (31/101) of the participants were receiving anti-retroviral therapy (ART) at TB diagnosis. At baseline, 41\% (41/101) had chest pain, 27\% (27/ $101)$ had difficulty in breathing, $94 \%(95 / 101)$ had a cough and $89 \%(90 / 101)$ had sputum production with a median cough duration of 4 weeks (IQR, 3-12, $n=95$ ) (Table 1).

TB was diagnosed by direct microscopy (smear), genexpert-MTB/RIF ${ }^{\oplus}$, Mycobacteria growth indicator tube (MGIT) and Löwenstein-Jensen (LJ) culture. Only 47\% (46/97) of the participants had positive sputum smears at TB diagnosis and 73\% (24/33) had positive sputum genexpert MTB/RIF results. $68 \%(64 / 94)$ of the participants had positive MGIT while $60 \%$ (55/92) had positive LJ cultures. For participants who had chest $\mathrm{x}$-rays done at baseline, 91\% (80/88) had abnormal x-rays. The commonest chest $\mathrm{x}$-ray abnormalities registered were pulmonary infiltrates (91\% [73/80]) followed by pleural effusion (19\% [15/80]) and cavities (6\% [5/80]) (Table 1).

\section{Aspergillus-specific IgG antibody levels using ImmunoCAP ${ }^{\circledR}$}

Using the ImmunoCAP immunoassay, the baseline median Aspergillus-specific IgG antibody levels were $4.43 \mathrm{mg} /$ 1 (IQR, 2.07-7.17) with 4\% (3/76) of the patients having elevated levels (>40 mg/l); while at week 24, the median Aspergillus-specific IgG antibody levels were $4.9 \mathrm{mg} / \mathrm{l}$ (IQR, 2.13-9.14) with $2 \%(2 / 94)$ having elevated levels (Table 2). All three patients who were positive for Aspergillus-specific IgG at baseline had become sero-negative by week 24 without antifungal treatment. Their $\mathrm{x}$-rays had also improved with a normal picture at week 24 .

Seven patients were negative for all the TB diagnostics (i.e. smear, genexpert, MGIT, LJ) but with abnormal chest $\mathrm{x}$-rays. For these patients, a presumptive diagnosis of TB was made based on the abnormal chest $\mathrm{x}$-ray. However, on comparing the baseline and week $24 \mathrm{x}$-rays, they all showed marked improvement, but only two had normal week 24 x-rays. These seven patients had Aspergillus-specific IgG antibodies in the range of $<2$ to $7.22 \mathrm{mg} / \mathrm{l}$ at baseline and $<2$ to $21.8 \mathrm{mg} / \mathrm{l}$ at week 24 . The higher titers at week 24 than baseline could suggest that there is an

Table 1 Characteristics of the study population at TB diagnosis

\begin{tabular}{|c|c|c|}
\hline Descriptions & $\mathrm{N}$ & Statistics \\
\hline \multicolumn{3}{|l|}{ Baseline Demographics } \\
\hline Males, n (\%) & 101 & $56(56)$ \\
\hline $\begin{array}{l}\text { Age at TB diagnosis, mean } \\
\text { (SD)/ median (IQR) }\end{array}$ & 101 & $34(8) / 33(27,38)$ \\
\hline On ART at TB diagnosis, n (\%) & 101 & $31(31)$ \\
\hline $\begin{array}{l}\text { CD4 (cells/ } \mu \mathrm{L}) \text { at TB diagnosis, } \\
\text { median (IQR) }\end{array}$ & 98 & $155(31,269)$ \\
\hline \multicolumn{3}{|c|}{ Respiratory symptoms at TB diagnosis } \\
\hline Cough, n (\%) & 101 & $95(94)$ \\
\hline $\begin{array}{l}\text { Cough duration in weeks, } \\
\text { median (IQR) }\end{array}$ & 95 & $4(3,12)$ \\
\hline Chest pain, $\mathrm{n}(\%)$ & 101 & $41(41)$ \\
\hline Difficulty in breathing, n (\%) & 101 & $27(27)$ \\
\hline \multicolumn{3}{|l|}{ TB diagnostics } \\
\hline Positive Sputum smear, n (\%) ${ }^{\mathrm{a}}$ & 97 & $46(47)$ \\
\hline Abnormal Chest X-ray, n (\%) & 88 & $80(91)$ \\
\hline $\begin{array}{l}\text { Pulmonary Infiltrates on chest } \\
\text { x-ray, } n(\%)^{a}\end{array}$ & 80 & $73(91)$ \\
\hline $\begin{array}{l}\text { Pleural Effusion on chest } \\
\text { x-ray, } \mathrm{n}(\%)^{\mathrm{a}}\end{array}$ & 80 & $15(19)$ \\
\hline Cavities on chest $\mathrm{x}$-ray, $\mathrm{n}(\%)^{\mathrm{a}}$ & 80 & $5(6)$ \\
\hline Positive Genexpert, n (\%) ${ }^{a}$ & 33 & $24(73)$ \\
\hline Positive MGIT, n(\%) & 94 & $64(68)$ \\
\hline Positive $\sqcup J$ culture, $n(\%)^{a}$ & 92 & $55(60)$ \\
\hline
\end{tabular}

Data presented are percentages (\%), standard deviations (SD) and interquartile ranges (IQR)

$E H$ ethambutol and Isoniazid, $R H$ rifampicin and Isoniazid, MGIT Mycobacteria growth indicator tube, $L J$ Löwenstein-Jensen

${ }^{\text {a }}$ Some parameters have $N<101$ due to missing data 
Table 2 Summary of Aspergillus-specific antibody titers and total serum IgE in HIV/TB patients in relation to selected baseline characteristics

\begin{tabular}{|c|c|c|c|c|c|c|c|c|}
\hline \multirow[t]{2}{*}{ Test/ Assay/ Cut-off } & \multirow[t]{2}{*}{ Factor at TB diagnosis } & \multicolumn{3}{|c|}{ BASELINE } & \multicolumn{3}{|c|}{ WEEK 24} & \multirow{2}{*}{$\begin{array}{l}\text { Overall } \\
\text { P value }\end{array}$} \\
\hline & & $\mathrm{N}$ & Median (IQR) & $P$ value* & $\mathrm{N}$ & Median (IQR) & $P$ value* & \\
\hline \multirow{11}{*}{$\begin{array}{l}\text { Aspergillus lgG } \\
\text { ImmunoCAP® } \\
\text { cut-off }=40 \text { mg/L }\end{array}$} & Overall & 76 & $4.4(2.1,7.2)$ & NA & 94 & $4.9(2.1,9.1)$ & $\mathrm{NA}$ & \multirow[t]{11}{*}{0.02} \\
\hline & Not on ART & 52 & $4.3(2.1,7.3)$ & \multirow[t]{2}{*}{0.85} & 65 & $4.9(2.7,10.4)$ & \multirow[t]{2}{*}{0.35} & \\
\hline & On ART & 24 & $4.8(2.0,6.9)$ & & 28 & $2.8(2.0,7.5)$ & & \\
\hline & $\mathrm{CD} 4<100 / \mu \mathrm{L}$ & 26 & $6.2(2.7,8.7)$ & \multirow[t]{2}{*}{0.01} & 31 & $5.3(2.1,12.7)$ & \multirow[t]{2}{*}{0.47} & \\
\hline & $\mathrm{CD} 4 \geq 100 / \mu \mathrm{L}$ & 47 & $3.2(2.0,6.0)$ & & 59 & $4.8(2.1,7.5)$ & & \\
\hline & $\begin{array}{l}\text { Coughed for } \\
<3 \text { weeks }\end{array}$ & 27 & $5.2(2.1,8.5)$ & \multirow[t]{2}{*}{0.50} & 29 & $4.9(2.3,10.4)$ & \multirow[t]{2}{*}{0.96} & \\
\hline & $\begin{array}{l}\text { Coughed for } \\
\geq 3 \text { weeks }\end{array}$ & 49 & $4.3(2.0,7.1)$ & & 64 & $4.9(2.1,9.0)$ & & \\
\hline & No Chest pain & 41 & $5.4(2.7,8.2)$ & \multirow[t]{2}{*}{0.03} & 55 & $4.8(2.1,8.8)$ & \multirow[t]{2}{*}{0.95} & \\
\hline & Chest pain & 35 & $2.9(2.0,6.2)$ & & 38 & $5.1(2.4,10.1)$ & & \\
\hline & $\begin{array}{l}\text { Abnormal Chest } \\
\text { X-Ray }\end{array}$ & 59 & $4.3(2.0,7.1)$ & \multirow[t]{2}{*}{0.79} & 75 & $4.9(2.1,8.8)$ & \multirow[t]{2}{*}{0.88} & \\
\hline & $\begin{array}{l}\text { Normal Chest } \\
\text { X-Ray }\end{array}$ & 6 & $3.9(2.6,8.7)$ & & 6 & $3.1(2.1,10.9)$ & & \\
\hline \multirow{11}{*}{$\begin{array}{l}\text { Aspergillus lgG } \\
\text { Immulite } \\
\text { cut-off }=20 \text { mg/L }\end{array}$} & Overall & 75 & $7.5(6.1,10.3)$ & NA & 87 & $7.2(6.1,9.96)$ & NA & \multirow[t]{11}{*}{0.66} \\
\hline & Not on ART & 52 & $8.0(6.7,10.6)$ & 0.03 & 61 & $7.6(6.2,10.5)$ & 0.27 & \\
\hline & On ART & 23 & $6.6(5.8,8.2)$ & & 26 & $6.9(6.1,8.8)$ & & \\
\hline & $\mathrm{CD} 4<100 / \mu \mathrm{L}$ & 25 & $7.9(5.9,9.1)$ & \multirow[t]{2}{*}{0.94} & 29 & $7.8(6.0,11.3)$ & \multirow[t]{2}{*}{0.60} & \\
\hline & $\mathrm{CD} 4 \geq 100 / \mu \mathrm{L}$ & 47 & $7.5(6.1,10.4)$ & & 56 & $7.0(6.1,9.5)$ & & \\
\hline & $\begin{array}{l}\text { Coughed for } \\
<3 \text { weeks }\end{array}$ & 26 & $7.3(6.0,8.8)$ & \multirow[t]{2}{*}{0.37} & 28 & $7.6(5.9,10.5)$ & \multirow[t]{2}{*}{0.98} & \\
\hline & $\begin{array}{l}\text { Coughed for } \\
\geq 3 \text { weeks }\end{array}$ & 49 & $7.5(6.4,10.7)$ & & 59 & $7.2(6.2,8.8)$ & & \\
\hline & No Chest pain & 40 & $7.5(6.4,10.8)$ & \multirow[t]{2}{*}{0.54} & 51 & $7.5(6.1,9.7)$ & \multirow[t]{2}{*}{0.92} & \\
\hline & Chest pain & 35 & $7.9(6.0,9,3)$ & & 36 & $7.2(6.1,10.8)$ & & \\
\hline & $\begin{array}{l}\text { Abnormal Chest } \\
\text { X-Ray }\end{array}$ & 58 & $7.5(6.1,9.1)$ & \multirow[t]{2}{*}{0.30} & 69 & $7.0(6.1,10.1)$ & 0.80 & \\
\hline & $\begin{array}{l}\text { Normal Chest } \\
\text { X-Ray }\end{array}$ & 6 & $6.8(5.0,8.2)$ & & 6 & $8.2(7.5,8.7)$ & & \\
\hline Total lgE & Overall & 76 & $379(129,908)$ & NA & 85 & $251(64,794)$ & NA & $<0.01$ \\
\hline $\begin{array}{l}\text { Immulite } \\
\text { cut-off }=1000 \mathrm{IU} / \mathrm{mL}\end{array}$ & Not on ART & 52 & $371(122,1059)$ & 0.82 & 59 & $297(55,1021)$ & 0.53 & \\
\hline & On ART & 24 & $382(175,837)$ & & 26 & $231(77,777)$ & & \\
\hline & $\mathrm{CD} 4<100 / \mu \mathrm{L}$ & 26 & $462(149,1440)$ & 0.11 & 29 & $595(113,1272)$ & 0.03 & \\
\hline & $\mathrm{CD} 4 \geq 100 / \mu \mathrm{L}$ & 47 & $355(114,634)$ & & 54 & $185(57,532)$ & & \\
\hline & $\begin{array}{l}\text { Coughed for } \\
<3 \text { weeks }\end{array}$ & 27 & $207(48,489)$ & 0.02 & 26 & $213(39,821)$ & 0.49 & \\
\hline & $\begin{array}{l}\text { Coughed for } \\
\geq 3 \text { weeks }\end{array}$ & 49 & $493(172,1200)$ & & 59 & $359(71,794)$ & & \\
\hline & No Chest pain & 41 & $355(149,605)$ & 0.40 & 49 & $183(55,570)$ & 0.06 & \\
\hline & Chest pain & 35 & $489(121,1221)$ & & 36 & $460(72,1192)$ & & \\
\hline & $\begin{array}{l}\text { Abnormal Chest } \\
\text { X-Ray }\end{array}$ & 59 & $457(149,1055)$ & 0.53 & 68 & $332(66,835)$ & 0.54 & \\
\hline & $\begin{array}{l}\text { Normal Chest } \\
\text { X-Ray }\end{array}$ & 6 & $401(322,1487)$ & & 6 & $153(73,292)$ & & \\
\hline & & & & & & NORMAL $(\leq 0.35), \mathrm{n}(\%)$ & $\mathrm{HIGH}(>0.35), \mathrm{n}(\%)$ & P-VALUE \\
\hline Aspergillus lgE & Overall, $N=93$ & $\mathrm{NOT}$ & APPLICABLE & & & $84(90.3)$ & $9(9.7)$ & \\
\hline
\end{tabular}


Table 2 Summary of Aspergillus-specific antibody titers and total serum lgE in HIV/TB patients in relation to selected baseline characteristics (Continued)

\begin{tabular}{|c|c|c|c|c|c|c|c|c|}
\hline \multirow[t]{2}{*}{ Test/ Assay/ Cut-off } & \multirow[t]{2}{*}{ Factor at TB diagnosis } & \multicolumn{3}{|c|}{ BASELINE } & \multicolumn{3}{|c|}{ WEEK 24} & \multirow{2}{*}{$\begin{array}{l}\text { Overall } \\
\text { P value }\end{array}$} \\
\hline & & $\mathrm{N}$ & Median (IQR) & $P$ value* & $\mathrm{N}$ & Median (IQR) & $P$ value* & \\
\hline \multirow{10}{*}{$\begin{array}{l}\text { ImmunoCAP }{ }^{\oplus} \\
\text { cut-off }=0.35 \mathrm{kU} / \mathrm{L}\end{array}$} & Not on ART & & & & & $59(90.8)$ & $6(9.2)$ & \multirow[t]{2}{*}{0.99} \\
\hline & On ART & & & & & 25(89.3) & $3(10.7)$ & \\
\hline & $\mathrm{CD} 4<100 / \mu \mathrm{L}$ & & & & & $26(83.9)$ & $5(16.1)$ & \multirow[t]{2}{*}{0.26} \\
\hline & $\mathrm{CD} 4 \geq 100 / \mu \mathrm{L}$ & & & & & $56(93.3)$ & $4(6.7)$ & \\
\hline & $\begin{array}{l}\text { Coughed for } \\
<3 \text { weeks }\end{array}$ & & & & & $25(86.2)$ & $4(13.8)$ & \multirow[t]{2}{*}{0.45} \\
\hline & $\begin{array}{l}\text { Coughed for } \\
\geq 3 \text { weeks }\end{array}$ & & & & & $59(92.2)$ & $5(7.8)$ & \\
\hline & No Chest pain & & & & & $51(92.7)$ & $4(7.3)$ & \multirow[t]{2}{*}{0.48} \\
\hline & Chest pain & & & & & $33(86.8)$ & $5(13.2)$ & \\
\hline & $\begin{array}{l}\text { Abnormal Chest } \\
\text { X-Ray }\end{array}$ & & & & & $67(89.3)$ & $8(10.7)$ & \multirow[t]{2}{*}{0.99} \\
\hline & $\begin{array}{l}\text { Normal Chest } \\
\text { X-Ray }\end{array}$ & & & & & 6(100.0) & $0(0.0)$ & \\
\hline
\end{tabular}

Data presented are diagnostic cut-offs, antibody median (interquartile ranges) and $P$-values comparing antibody titers between selected parameters, baseline and end of TB treatment (wk24)

NA not applicable

*P-values were obtained using Kruskal-Wallis equality-of-populations rank test. \$ $P$-values were obtained using Wilcoxon matched-pairs sign-rank test because of skewed data

increase in the aspergillus colonization due to the increasing pulmonary abnormalities especially cavities caused by TB. However, for these seven patients, both titers were below the diagnostic cut-off and not significantly different $(P>0.05)$.

There was a significant difference in the Aspergillusspecific IgG antibody levels between baseline and week
$24(P=0.02)$ (Fig 1a). Patients with a baseline CD4 Tcell count $<100$ cells $/ \mu$ l had significantly higher median baseline Aspergillus-specific IgG titers $(n=26$, median $=$ $6.2 \mathrm{mg} / \mathrm{l}, \mathrm{IQR}=2.7$ to 8.7 ) than those with a baseline CD4 T-cell count of $\geq 100$ cells $/ \mu l \quad(n=47$, median $=$ $3.2 \mathrm{mg} / \mathrm{l}, \mathrm{IQR}=2.0$ to 6.0$)(P=0.01)$. Patients with chest
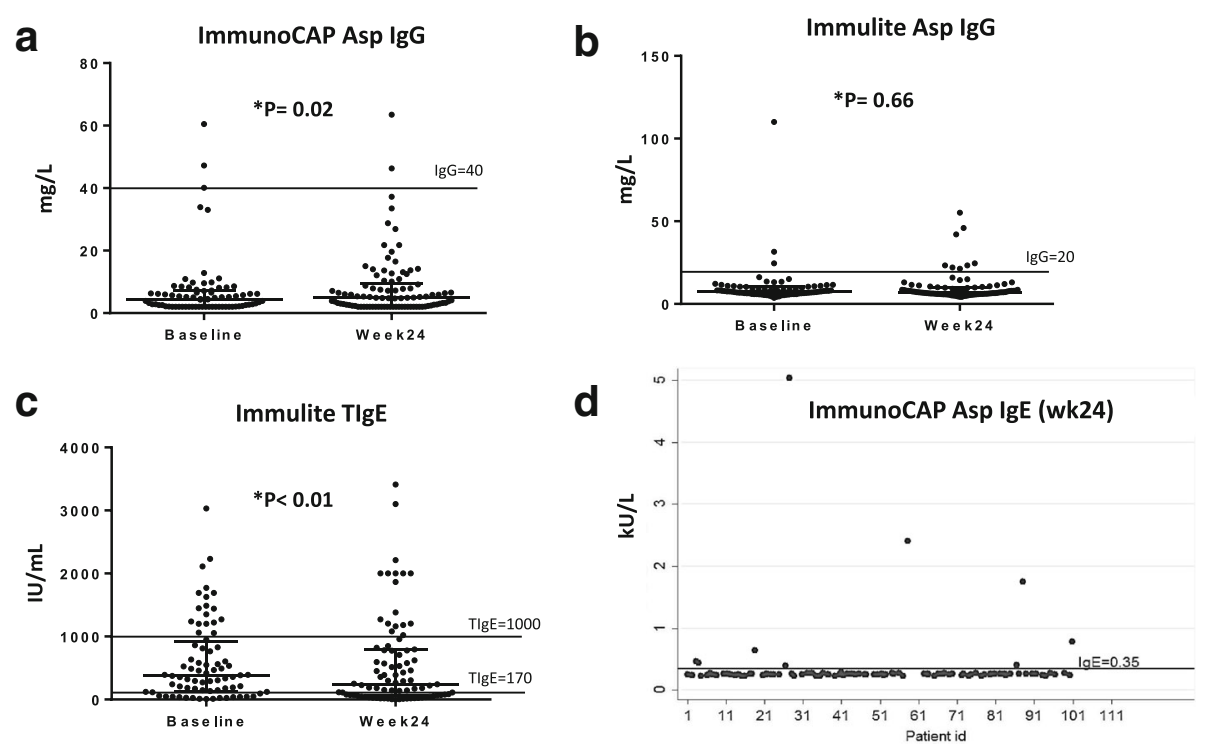

Fig. 1 Scatter plots of antibody levels at baseline and week 24. a Shows a significant difference in Aspergillus-specific lgG levels between baseline and week 24 using ImmunoCAP. b Shows no significant difference in Aspergillus-specific IgG levels between baseline and week 24 using Immulite. c Shows a significant difference in total serum IgE levels between baseline and week 24 using Immulite. $\mathbf{d}$ Shows distribution of Aspergillus-specific lgE levels at week 24 
pain at baseline had significantly lower median Aspergillus-specific IgG titers $(n=35$, median $=2.9 \mathrm{mg} / \mathrm{l}$, IQR $=$ 2.0 to 6.2$)$ than those without chest pain $(n=41$, median $=5.4 \mathrm{mg} / \mathrm{l}, \mathrm{IQR}=2.7$ to 8.2$)(P=0.03)$ (Table 2$)$. Chest pain is not a specific symptom. Out of the 41/101 patients who had chest pain, only one had elevated IgG levels. Out of the 60/101 patients without chest pain, only two had elevated IgG levels. The observed outcome could be explained by other factors related to TB but not CPA.

\section{Aspergillus-specific IgG antibody levels using Immulite $2000^{\circledR}$}

Using the Immulite immunoassay, the median Aspergillusspecific IgG antibody levels were $7.52 \mathrm{mg} / \mathrm{l}$ (IQR, 6.08$10.3)$ with $4 \%(3 / 75)$ of the patients having elevated titers at baseline; while at end of week 24, the median Aspergillus-specific IgG antibody levels were $7.21 \mathrm{mg} / \mathrm{l}$ (IQR, 6.08-9.96) with 9.2\% (8/87) having elevated levels (Table 2). Only three patients (different from the 3 in ImmunoCAP) were positive at baseline and two of them remained positive at week 24, but with lower antibody titers. Seven patients were negative for all the TB diagnostics (i.e. smear, genexpert, MGIT, LJ) but with abnormal chest x-rays. These seven patients had aspergillus IgG antibodies in the range of 4.26 to $8.23 \mathrm{mg} / \mathrm{l}$ at baseline and 4.31 to $14.9 \mathrm{mg} /$ $\mathrm{l}$ at week 24 .

There was no significant difference in the Aspergillusspecific IgG antibody levels between baseline and week 24 $(p=0.66)$ (Fig 1b). Patients who were not on antiretroviral therapy at TB diagnosis had significantly higher median Aspergillus-specific IgG titers $(n=52$, median $=8.0 \mathrm{mg} / \mathrm{l}$, $\mathrm{IQR}=6.7$ to 10.6$)$ than those who were already taking antiretroviral therapy at $\mathrm{TB}$ diagnosis $(n=23$, median $=$ $6.6 \mathrm{mg} / \mathrm{l}, \mathrm{IQR}=5.8$ to 8.2$)(P=0.03)$ (Table 2).

\section{Total serum IgE using Immulite $2000^{\circledR}$}

Total serum IgE was measured using Immulite assay with a cut-off of $170 \mathrm{IU} / \mathrm{ml}$. The median total serum IgE levels were $379 \mathrm{IU} / \mathrm{ml}$ (IQR, 129-908) with 71\% (54/76) of the patients having elevated titers at baseline; while at week 24, the median total serum IgE levels were $251 \mathrm{IU} /$ $\mathrm{ml}$ (IQR, 64-794) with 58\% (49/85) of patients having elevated levels (Table 2 ). We then analyzed results using a cut-off to $1000 \mathrm{IU} / \mathrm{ml}$. Only 24\% (18/76) of the patients had total serum IgE greater than $1000 \mathrm{IU} / \mathrm{mL}$ at baseline and $21 \%(18 / 85)$ at week 24 . There was a significant difference in the total serum IgE antibody levels between baseline and week $24(p<0.01)$ (Fig 1c).

Patients who had coughed for more than three weeks at $\mathrm{TB}$ diagnosis had significantly higher median total serum IgE titers $(n=49$, median $=493 \mathrm{IU} / \mathrm{ml}, \mathrm{IQR}=172$ to 1200) than those who had coughed for less than three weeks at TB diagnosis $(n=27$, median $=207 \mathrm{IU} / \mathrm{ml}, \mathrm{IQR}$
$=48$ to 489$)(P=0.02)$. Patients with a CD4 T-cell count $<100$ cells/ $\mu$ l at week 24 , had significantly higher median total serum IgE titers $(n=29$, median $=595 \mathrm{IU} / \mathrm{ml}, \mathrm{IQR}$ $=113$ to 1272 ) than those with a baseline CD4 T-cell count of $\geq 100$ cells $/ \mu \mathrm{l}$ ( $n=54$, median $=185 \mathrm{IU} / \mathrm{ml}, \mathrm{IQR}$ $=57$ to 532$)(P=0.03)$ (Table 2$)$.

\section{Aspergillus-specific IgE antibody levels using ImmunoCAP ${ }^{\circledR}$}

Aspergillus-specific IgE antibody levels were measured at end of TB treatment only (Fig 1d), and were elevated in $9.7 \%(9 / 93)$ of the patients using a diagnostic cut-off of $<0.35 \mathrm{kU} / \mathrm{l}$ (Table 2). There was no significant relationship between Aspergillus sensitization (Asp IgE) and baseline characteristics or respiratory symptoms.

\section{Discussion}

The study demonstrated that Aspergillus-specific IgG antibodies were elevated in $4 \%$ of HIV-infected Ugandan adults at the start of TB treatment and in 9\% at the end of TB treatment. Using ImmunoCAP, participants with CD4 T-cell counts $<100$ cell $/ \mu$ l had more elevated Aspergillusspecific IgG antibodies $(P=0.01)$. The increased level of immunosuppression could have increased their susceptibility to the opportunistic fungal infection. Hyper IgG levels are common in acquired immune deficiency syndrome (AIDS) patients and represent an unrestrained Bcell response in the absence of T-cells [14]. The ImmunoCAP Aspergillus-specific IgG antibody titers were higher with more positives at end of TB treatment than baseline, even though the difference in means was small. However, this difference was statistically significant $(P=0.02)$. Initiation of antiretroviral therapy and anti-TB medication could have improved the patients' ability to mount a good immune response at week 24 than baseline.

Patients who were not on antiretroviral therapy at TB diagnosis (68\%) had significantly higher Aspergillus-specific IgG titers $(P=0.03)$ using Immulite, and $45 \%(14 /$ 31 ) of them had CD4 T-cell counts less than 200 cells/ $\mu \mathrm{l}$. Increased level of immunosuppression could still be the contributing factor to this increased susceptibility to the opportunistic fungal infection. There was no significant difference in the Immulite Aspergillus-specific IgG antibody levels $(P=0.66)$ between baseline and end of TB treatment.

We observed a discrepancy in the Aspergillus-specific IgG antibody levels between the ImmunoCAP and Immulite. Previous studies comparing the ImmunoCAP and Immulite have shown that the values for both tests are highly correlated with antibody levels measured by Immulite having a mean of 3 times higher than when measured by ImmunoCAP. However, this correlation is lost at high ImmunoCAP values [15]. This ratio may change based on the specific antibody in question. In 
our current study, this ratio was approximately 1.6 on average.

About 10\% (9/93) of the participants had evidence of Aspergillus sensitization at the end of TB treatment. This was an expected outcome in this population since persistence of pulmonary cavities after successful pulmonary TB treatment is very common [16] and these cavities are thought to harbour mould spores leading to fungal colonisation. Besides, ABPA can be misdiagnosed as pulmonary TB, with some similar clinical features [10, 17]. However, ABPA is rarely described outside chronic obstructive pulmonary disease (COPD), asthma and cystic fibrosis. There was no record of these three conditions in our participants, and therefore we argue that Aspergillus sensitisation is the explanation for these high IgE results, which could represent a strong T-helper 2 (Th2) response. The association between ABPA and pulmonary TB has been weakly described before mainly in case reports [18-20].

In a recent review, CPA in Uganda was estimated to affect up to $22 \%$ of TB patients with cavities and $4 \%$ in those without cavities [3]. However, in the current population, pulmonary infiltrates were the most common chest $\mathrm{x}$ ray abnormality both at baseline (91\%) and week $24(41 \%)$. Only $5 \%$ of our participants had pulmonary cavities on chest $\mathrm{x}$-ray at week 24 . This did not change much from the $6 \%$ cavities registered at baseline. All the five patients with cavities at week 24 had a good treatment outcome (cured) but 3/5 had been diagnosed with smear negative TB at baseline. This result supports previous work indicating persistence of pulmonary cavities after successful pulmonary TB treatment [16].

At week 24, 95\% (95/100) of the chest $\mathrm{x}$-rays showed marked improvement from the baseline chest $\mathrm{x}$-rays and only $52 \%(52 / 100)$ were abnormal. Using ImmunoCAP, all patients with normal and abnormal chest $\mathrm{x}$-rays at week 24 were negative for Aspergillus-specific IgG (range: $<2$ to 9). However, using Immulite, there were five positives among those with normal chest x-ray (median 7 [IQR: 5.9, 9.2]) and three positives among those with abnormal chest x-rays (median 7.6 [IQR: 6.3, 10.3]). We were unable to do computed tomography (CT) scans of the chest, which might have provided better definition of any residual abnormalities.

Total serum IgE is a test for general allergic disease and parasitic infections. It is commonly used together with fungal-allergy diagnostics. Using a cut-off of $170 \mathrm{IU} /$ $\mathrm{ml}$ for total serum IgE antibodies, $71 \%$ of participants had evidence of allergic disease. This reduced to $58 \%$ $(49 / 85)$ at the end of TB treatment. Of these 49 participants with elevated total serum IgE antibodies at the end of TB treatment, 12\% (6/49) had elevated Aspergillusspecific IgE antibody titers in the range of 0.41 to 2.4, and Aspergillus-specific IgG antibody titers in the range of 6.7 to 55.2 .
The implication of the raised total serum IgE levels in this population was not obvious. However, there is evidence that total serum IgE levels tend to be more elevated in non-asthmatic Africans than asthmatic Africans [21]. Most scholars attribute this paradox to parasitic infestations in the African population [21, 22]. This paradox therefore calls for the need to re-evaluate the role of total serum IgE levels in asthma in areas with a high gut parasite prevalence. Recent evidence from genotyping ancestry informative markers indicated that African ancestry is a risk factor for elevated total serum IgE levels in African admixed population [23]. Intestinal helminths are also known to raise total serum IgE levels in HIV patients even without a fully functional CD4 T-cell repertoire [24-26].

Raising the cut-off for total serum IgE to $1000 \mathrm{IU} / \mathrm{mL}$ reduced the positivity rate to more than $50 \%$. Only 18 participants had total serum IgE greater than $1000 \mathrm{IU} / \mathrm{mL}$ at the end of TB treatment. Of these, $28 \%$ (5/18) had elevated Aspergillus-specific IgE antibody titers in the range of 0.41 to 2.4 , and only two of these (2/5) had elevated $A s$ pergillus-specific IgG antibody titers (Immulite). Long term coughing for more than three weeks at baseline was also significantly related to increased total serum IgE titers $(P=0.02)$. It is possible that some participants had both TB and some form of allergy at baseline; which would explain the prolonged cough durations.

$53 \%$ (51/97) of the patients had negative sputum smears. Smear-negative tuberculosis was registered in 13 to $21 \%$ of our participants at baseline. Among smear negative patients $(n=51)$, there were 16 positive genexperts, 20 positive MGIT and 13 positive LJ cultures. Seven patients were negative for all the TB diagnostics (i.e. smear, genexpert, MGIT, LJ) but with abnormal chest $\mathrm{x}$-rays. These seven patients were negative for Aspergillus IgG antibodies with very low titers at both baseline and week 24. CPA associated with TB constitutes a significant unrecognized public health problem, which is probably being incorrectly identified as 'smear-negative tuberculosis' especially in Africa.

Based on data from India, reduced pulmonary function is associated with Aspergillus sensitisation, which unfortunately we were unable to measure. Post-tuberculous sequelae include CPA, bronchiectasis [10] and to this we add Aspergillus sensitisation. Reduced pulmonary function persists in patients cured of TB [27], and Aspergillus sensitisation could be one of the explanations, through poorly understood mechanisms. The prevalence of pulmonary Aspergillosis in HIV patients is underestimated in Africa because of difficulty in accurate diagnosis. We have only had a few epidemiological studies in Uganda $[4,6,8]$. However, in collaboration with The Global Action Fund for Fungal Infections (GAFFI) and the University of Manchester, efforts are being put in place to train more mycologist and build laboratory capacity in Uganda. We hope that this might solve the problem in the near future. 


\section{Study limitations}

The major limitation to the study was that we failed to access control samples for comparison of these antibody titers. This would possibly give more useful information. So we agreed to move on without the controls since the primary goal of this study was not to define diagnostic cut-offs for assays that might subsequently be used in a prevalence study in Uganda. Due to the limited published data on fungal disease epidemiology in subSaharan Africa, we found a major challenge in defining which diagnostic cut-offs to use for Aspergillus-specific IgG antibodies in both ImmunoCAP and Immulite. Previously published cut-offs range in 10 to $50 \mathrm{mg} / \mathrm{l}$ in similar populations. We were unable to do computed tomography $(\mathrm{CT})$ scans of the chest, which might have provided better definition of any residual abnormalities. Similarly, we did not add other tests like culture since we used stored serum samples. Intestinal helminths are known to raise total serum IgE levels in HIV patients even without a fully functional CD4 T-cell repertoire [24-26]. So the implication of the raised total serum IgE levels in this population was not obvious. We observed a discrepancy in the Aspergillus-specific IgG antibody levels between the ImmunoCAP and Immulite similar to what has been described before [15]. Cavities are known to be the major predisposing factor to CPA in TB. However, in our population, cavities were seen in only $5 \%$ of the participants.

\section{Conclusion}

In conclusion, Aspergillus-specific antibody levels were significantly raised in patients being managed for pulmonary tuberculosis. This colonization and/or sensitization by Aspergillus antigens may complicate disease progression and treatment outcomes among TB patients. Detection of Aspergillus antibodies is an indispensable tool in the diagnosis and management of the patients with pulmonary aspergillosis. However, the detection of Aspergillus-specific antibodies does not imply that the patient has an active fungal disease; further diagnostic tests would be needed to ascertain the presence of pulmonary aspergillosis. More epidemiological studies are needed to explore and expand the utility of Aspergillus antibody testing in resource limited setting.

\section{Additional file}

Additional file 1: Study raw data. File contains a full set of raw data for the tests performed and baseline clinical and demographics characteristics. (XLSX 51 kb)

\section{Abbreviations}

ABPA: Allergic bronchopulmonary aspergillosis; ART: Antiretroviral therapy; CD4: Cluster of differentiation 4; COPD: Chronic obstructive pulmonary disease; CPA: Chronic Pulmonary Aspergillosis; CT: Computerized
Tomography; Fig: Fig.; HIV: Human immunodeficiency virus; HR: Isoniazid and Rifampicin; HRZE: Isoniazid, Rifampicin, Pyrazinamide and Ethambutol; IDI: Infectious Diseases Institute; IgE: Immunoglobulin E; IgG: Immunoglobulin G; IQR: Interquartile range; ISID: International Society for Infectious Diseases; LJ: Löwenstein-Jensen; MGIT: Mycobacteria growth indicator tube; SD: Standard deviation, n- sample size; SOUTH: Study on Outcomes related to Tuberculosis and HIV drug concentrations In Uganda; TB: Tuberculosis; Th2: T Helper Type 2 Cell; UK: United Kingdom; WHO: World Health Organisation

\section{Acknowledgements}

We would like to acknowledge all our participants and their families. We especially thank the team of the TB/HIV clinic at the IDI in Kampala for patient care. We also thank Mr. Allan Buzibye for laboratory support during retrieving and shipping samples.

\section{Funding}

This study was funded by the collaboration between the Infectious Diseases Institute (IDI) Makerere University and the University of Zurich (supported by Abbvie, Bristol Myers Squibb, Gilead Sciences, Janssen, Lunge Zurich, Merck, Shimadzu, Swiss HIV Cohort Study, ViiV Healthcare) and a grant from the International Society for Infectious Diseases (ISID) to Richard Kwizera. Siemens ${ }^{\circledR}$ Company donated to us the Immulite test kits and the Laboratory at Christie Hospital, Manchester allowed us to use their Immulite 2000 machine for free. Richard Kwizera is also currently supported by a THRiVE-2 PhD fellowship (THRiVE is being supported through the DELTAS Africa Initiative [107,742/Z/15/Z]). The funders had no role in study design, data collection and analysis, decision to publish, or preparation of the manuscript.

\section{Availability of data and materials}

All data generated or analysed during this study are included in this published article and its supplementary information files. The authors confirm that all data underlying the findings are fully available without restriction and can be availed by contacting Mr. Richard Kwizera (kwizerarichard@ymail.com).

\section{Authors' contributions}

RK, RPR, DWD conceived and designed concept. RK, IP performed experiments. RK, JM, IP analysed data. RK, IP, DWD contributed reagents/ materials/analysis tools. RK, JM, IP, CS participated in initial manuscript drafting. RK, CS, JF, BC, AK, IP, RPR, DWD participated in critical revisions for intellectual content. RK, RPR, DWD, BC, AK, JF participated in obtaining funding. CS, AK, RPR participated in administrative, technical, or material support. All authors have read and approved the manuscript.

\section{Ethics approval and consent to participate}

Participants provided written informed consent to participate in the SOUTH study. Ethics approval for this sub-study was received from the Joint Clinical and Research Centre Institutional Review Board, the Uganda National Council for Science and Technology and the Uganda National Drug Authority.

\section{Consent for publication}

Not applicable.

Competing interests

The authors declare that they have no competing interests.

\section{Publisher's Note}

Springer Nature remains neutral with regard to jurisdictional claims in published maps and institutional affiliations.

\section{Author details}

${ }^{1}$ Infectious Diseases Institute, College of Health Sciences, Makerere University, P.O.BOX 22418 Kampala, Uganda. ${ }^{2}$ Cambridge Institute of Public Health, University of Cambridge, Cambridge, UK. ${ }^{3}$ The University of Manchester, Manchester, UK. ${ }^{4}$ National Aspergillosis Centre, University Hospital of South Manchester, Manchester, UK. ${ }^{5}$ Infectious Diseases and Hospital Hygiene, University Hospital, Zurich, Switzerland. 
Received: 6 June 2017 Accepted: 14 November 2017

Published online: 21 November 2017

\section{References}

1. Keeler E, Perkins MD, Small P, Hanson C, Reed S, Cunningham J, Aledort JE, Hillborne L, Rafael ME, Girosi F. Reducing the global burden of tuberculosis: the contribution of improved diagnostics. Nature. 2006:444:49-57.

2. GLOBAL TUBERCULOSIS REPORT 2016. http://www.who.int/tb/publications/ global_report/en/.

3. Parkes-Ratanshi R, Achan B, Kwizera R, Kambugu A, Meya D, Denning D. Cryptococcal disease and the burden of other fungal diseases in Uganda; where are the knowledge gaps and how can we fill them? Mycoses. 2015; 58(S5):85-93.

4. Page I, Onyachi N, Opira C, Opwonya J, Odongo-Aginya E, Mockridge A, Byrne $G$, Richardson M, Denning D. Chronic pulmonary aspergillosis (CPA) is likely to be a common complication of pulmonary tuberculosis: initial results of a cross-sectional survey. In: 19th Congress of the International Society for Human and Animal Mycology; 2015. abstract No: EV0971.

5. Page I, Worodria W, Andama A, Ayakaka I, Kwizera R, Davis L, Huang L, Richardson M, Denning D. Onset of chronic pulmonary Aspergillosis (Cpa) may occur during active pulmonary tuberculosis. In: 7th advances against Aspergillosis conference. Manchester; 2016. abstract No: 100. http://www. aspergillus.org.uk/content/onset-chronic-pulmonary-aspergillosis-cpa-mayoccur-duringactive-pulmonary-tuberculosis-0.

6. Page ID, Worodria W, Andama A, Ayakaka I, Davis L, Huang L, Richardson M, Denning DW. Pulmonary aspergillosis may be common in AIDS with smear negative tuberculosis. In: Conference on retrovirus and opportunistic infections. Boston; 2016. POSTER NUMBER 764. http://www.croiconference. org/sites/default/files/posters-2016/764.pdf.

7. Page I, Kwizera R, Richardson M, Denning D. Comparative efficacy of five Aspergillus-specific lgG ELISAs for the diagnosis of chronic pulmonary aspergillosis (CPA). In: 25th EUROPEAN CONGRESS OF CLINICAL MICROBIOLOGY AND INFECTIOUS DISEASES. Denmark; 2015. abstract No: P1099. http://www. aspergillus.org.uk/content/comparative-efficacy-five-aspergillus-specific-igg-elisasdiagnosischronic-pulmonary.

8. Page I. Pulmonary aspergillosis in association with tuberculosis and HIV in Uganda. PhD Research thesis. research.manchester.ac.uk: The University of Manchester; 2015. https://www.research.manchester.ac.uk/portal/files/ 54577119/FULL TEXT.PDF.

9. Shafer LA, Biraro S, Nakiyingi-Miiro J, Kamali A, Ssematimba D, Ouma J, Ojwiya A, Hughes P, Van der Paal L, Whitworth J. HIV prevalence and incidence are no longer falling in southwest Uganda: evidence from a rural population cohort 1989-2005. AIDS (London, England). 2008;22(13):1641-9.

10. Dhooria S, Kumar P, Saikia B, Aggarwal A, Gupta D, Behera D, Chakrabarti A, Agarwal R. Prevalence of Aspergillus sensitisation in pulmonary tuberculosisrelated fibrocavitary disease. Int J Tuberc Lung Dis. 2014;18(7):850-5.

11. Sekaggya-Wiltshire $C$, von Braun A, Scherrer A, Manabe $Y$, Buzibye A, Muller D, Ledergerber B, Gutteck U, Corti N, Kambugu A. Anti-TB drug concentrations and drug-associated toxicities among TB/HIV-coinfected patients. J Antimicrob Chemother. 2017;72(4):1172-7.

12. Laurent J, Noirot C, Ansquer J, Laurent G, Kestenbaum S, Lagrue G. How to define the normal level of serum lgE in adults? In: Annales de medecine interne, vol. 1984; 1984. p. 419-22.

13. Tillie-Leblond I, Tonnel AB. Allergic bronchopulmonary aspergillosis. Allergy. 2005;60(8):1004-13.

14. Kaushik K, Khurana S, Wanchu A, Malla N. Serum immunoglobulin G, M and a response to Cryptosporidium Parvum in cryptosporidium-HIV co-infected patients. BMC Infect Dis. 2009;9:179.

15. Graham F, Begin P, Paradis L, Lacombe-Barrios J, Paradis J, Des Roches A. Comparison of ImmunoCAP and Immulite serum specific lgE assays for the assessment of egg allergy. Allergy, Asthma Clin Immunol. 2016;12:29.

16. Denning DW, Riniotis K, Dobrashian R, Sambatakou H. Chronic cavitary and Fibrosing pulmonary and pleural aspergillosis: case series, proposed nomenclature change, and review. Clin Infect Dis. 2003;37:S265-80.

17. Kant S. Allergic bronchopulmonary aspergillosis mimicking as pulmonary tuberculosis. Lung India. 2007;24(4):142.

18. Agarwal R, Singh N, Aggarwal A. An unusual association between mycobacterium tuberculosis and Aspergillus fumigatus. Monaldi Arch Chest Dis. 2016:69(1):32-4.
19. Min KH, Park SJ, Kim SR, Lee MH, Chung CR, Han HJ, Choi KH, Chung MJ, Lee YC, Jin GY. Coexistence of allergic bronchopulmonary aspergillosis and active pulmonary tuberculosis. Am J Respir Crit Care Med. 2011;183(1):137-9.

20. Gupta M, Roshan R, Chhabra SK. Allergic bronchopulmonary aspergillosis without asthma complicating pulmonary tuberculosis. Lung India. 2012; 29(3):286-8.

21. Scrivener S, Britton J. Immunoglobulin E and allergic disease in Africa. Clin Exp Allergy. 2000;30(3):304.

22. Houba $V$, Rowe D. A comparison of African and European serum levels of immunoglobulin E. Bull World Health Organ. 1973;49(6):539.

23. Vergara C, Murray T, Rafaels N, Lewis R, Campbell M, Foster C, Gao L, Faruque M, Oliveira RR, Carvalho E. African ancestry is a risk factor for asthma and high total lgE levels in African admixed populations. Genet Epidemiol. 2013;37(4):393-401.

24. Kassu A, Mohammad A, Fujimaki Y, Moges F, Elias D, Mekonnen F, Mengistu G, Yamato M, Wondmikun Y, Ota F. Serum IgE levels of tuberculosis patients in a tropical setup with high prevalence of HIV and intestinal parasitoses. Clin Exp Immunol. 2004;138(1):122-7.

25. Marth K, Wollmann E, Gallerano D, Ndlovu P, Makupe I, Valenta R, Sibanda E. Persistence of lgE-associated allergy and allergen-specific lgE despite CD4+ T cell loss in AIDS. PLoS One. 2014;9(6):e97893.

26. Mulu A, Anagaw B, Gelaw A, Ota F, Kassu A, Yifru S. Effect of deworming on Th2 immune response during HIV-helminths co-infection. J Transl Med. 2015;13(1):236.

27. Pasipanodya JG, Miller TL, Vecino M, Munguia G, Bae S, Drewyer G, Weis SE. Using the St. George respiratory questionnaire to ascertain health quality in persons with treated pulmonary tuberculosis. CHEST Journal. 2007;132(5):1591-8.

\section{Submit your next manuscript to BioMed Central and we will help you at every step:}

- We accept pre-submission inquiries

- Our selector tool helps you to find the most relevant journal

- We provide round the clock customer support

- Convenient online submission

- Thorough peer review

- Inclusion in PubMed and all major indexing services

- Maximum visibility for your research

Submit your manuscript at www.biomedcentral.com/submit
) Biomed Central 